\title{
Penyuluhan Resiko Kehamilan Pada Remaja di Pulau Nguan Kecamatan Galang Kota Batam Tahun 2020
}

\author{
Trisna Yuni Handayani, Renny Adelia Tarigan, Desi Pramita Sari, Norma Jeepi Margianti, \\ Suci Ridmadhanti, Nelli Roza \\ Prodi Diploma Tiga Kebidanan Institut Kesehatan Mitra Bunda Batam
}

\begin{abstract}
ABSTRAK
Kehamilan usia dini merupakan salah satu faktor kehamilan dengan risiko tinggi yang dapat mempengaruhi kesehatan ibu maupun pertumbuhan dan perkembangan janin. Belum matangnya organ reproduksi menyebabkan wanita yang hamil usia muda lebih beresiko. Berdasarkan data di Dinas Kesehatan Kota Batam (2019) kehamilan remaja pada wilayah kerja Galang dengan presentase 0,34\%.Pulau Nguan kecamatan galang merupakan daerah hinterland dengan akses ke pelayanan kesehatan yang jauh, sulitnya jaringan internet sehingga remaja kurang mendapatkan informasi kesehatan khususnya tentang kesehatan reproduksi. Kegiatan ini bertujuan untuk memberikan edukasi pada remaja sehingga dapat mencegah dan menurunkan angka kejadiannya khususnya di daerah kepulauan di Batam.
\end{abstract}

Kata Kunci: Kehamilan usia dini, Resiko, Remaja

\begin{abstract}
Teenager Pregnancy is one of the high risk pregnancy factors that can affect maternal health and fetal growth. The Reproductive organs that are not ready can cause teenager more risky to pregnant. Based on data in Department of Health Office Batam (2019) teenager pregnancy in Galang working area with a percentage of $0.34 \%$. Nguan Island is Galang Sub-district a hinterland area far from access to health services, the difficulty of the Internet network so that teenagers are not get health information especially about reproductive health. This activity aims to educate the teenager to prevent and reduce the incidences of teenager pregnancy especially in the archipelago area in Batam.
\end{abstract}

Keywords: early pregnancy, risk, teen 


\section{PENDAHULUAN}

Kesehatan reproduksi Remaja adalah keadaan sempurna fisik, mental dan kesejahteraan sosial dan tidak semata-mata ketiadaan penyakit atau kelemahan, dalam segala hal yang berkaitan dengan fungsi dan proses sistem reproduksi remaja ${ }^{1}$.

Berdasarkan laporan pelayanan kesehatan peduli remaja (PKPR) dari bagian kesehatan keluarga dan gizi Dinas Kesehatan Kota Batam, terdapat beberapa masalah kesehatan remaja yang menjadi tolak ukur pelayanan kesehatan remaja dan yang berhubungan erat dengan kesehatan reproduksi yaitu kehamilan remaja, persalinan remaja, HIV/AIDS pada remaja, Infeksi Menular Seksual, dan Infeksi Saluran Reproduksi².

Berdasarkan Data dinas kesehatan Kota Batam menunjukkan cakupan persentase Kehamilan diusia dini di wilayah kerja Puskesmas galang Kota Batam tahun 2019 yaitu 0,34 \%. Jumlah ini tidak terlalu banyak dibandingkan dengan beberapa wilayah kerja puskesmas lain di Kota Batam, Namun jika tidak ada penanganan jumlah ini akan meningkat ${ }^{3}$.

Berdasarkan studi pendahuluan yang dilakukan di Pulau Nguan kecamatan galang Kota Batam bahwa beberapa faktor yang menyebabkan terjadinya pernikahan diusia dini di Pulau Nguan adalah karena adanya faktor ekonomi, sehingga dapat meringankan beban orang tuanya maka anaknya dinikahkan dengan orang yang dianggap mampu. Faktor lain yaitu pendidikan, Rendahnya tingkat pendidikan maupun pengetahuan orang tua, menyebabkan adanya kecenderungan menikahkan anaknya yang masih dibawah umur. Orang tua khawatir anak perempuannya berpacaran dengan laki-laki yang sangat dekat sehingga segera menikahkan anaknya

Pulau Nguan kecamatan galang merupakan daerah hinterland dengan akses ke pelayanan kesehatan yang jauh, sulitnya jaringan internet sehingga remaja dan masyarakat kurang mendapatkan informasi kesehatan khususnya tentang kesehatan reproduksi. Remaja tidak memahami resiko kehamilan usia dini yang merupakan salah satu faktor resiko tinggi kehamilan yang dapat mempengaruhi kesehatan ibu maupun pertumbuhan dan perkembangan janin 


\section{Metode}

\section{A. Metode Kegiatan}

Secara umum kegiatan ini menggunakan metode pemberian edukasi secara Ceramah dan Diskusi. Kegiatan ceramah dan diskusi dilakukan untuk dapat meningkatkan pengetahuan serta memberikan pemahaman remaja tentang resiko kehamilan usia dini pada remaja diberikan oleh dosen prodi diploma tiga Kebidanan Institut Mitra Bunda . Materi yang diberikan yaitu tentang kesehatan reproduksi, berbagai macam persoalan ksesehatan reproduksi, pernikahan dini dan resiko kehamilan usia dini pada remaja.

\section{B. Prosedur dan Alat Evaluasi}

Untuk mengetahui program yang telah dilaksanakan ini berdampak positif bagi remaja di Pulau Nguan maka dibuat suatu evaluasi yang meliputi:

1. Dilakukan pre- test mengenai pengetahuan remaja tentang tentang kesehatan reproduksi, berbagai macam persoalan ksesehatan reproduksi, pernikahan dini dan resiko kehamilan usia dini pada remaja. Hal ini dilakukan sebelum kegiatan dilakukan untuk mengetahui seberapa besar pengetahuan remaja sebelum diberikan penyuluhan.

2. Dilakukan post test tentang materi- materi yang diberikan menyangkut apa yang diinformasikan saat ceramah,

3. Tanya jawab maupun diskusi bagi yang bisa menjawab pertanyaan dan bertanya diberikan bingkisan

4. Pembagian leaflet kepada remaja sehingga dapat dibaca oleh orangtuanya

5. Selanjutnya dibandingkan antara skor pre - test dan post test, sehingga akan dapat

dilihat keberhasilan kegiatan yang telah dilakukan.

\section{Teknik Analisis Data dan Kriteria Keberhasilan Program}

Data hasil tes baik pre test maupun post test tentang penyuluhan ini dianalisis dengan

teknik analisis deskriptif dan analitik.

\section{Partisipasi Remaja}


Jumlah partisipasi Remaja dalam kegiatan ini adalah 22 remaja putri, panitia 5 orang dosen serta mahasiswa.

\section{E. Jenis Luaran}

Luaran dari kegiatan ini adalah adanya peningkatan pengetahuan dan pemahaman remaja tentang tentang kesehatan reproduksi, berbagai macam persoalan ksesehatan reproduksi, pernikahan dini dan resiko kehamilan usia dini pada remaja. Selain itu kegiatan ini dapat berjalan berkesinambungan yang dapat dislaksanakan oleh pihak terkait di masa mendatang.

\section{HASIL DAN PEMBAHASAN}

Tahapan pada kegiatan yang dilakukan saat ini adalah masih pada bentuk peningkatan ilmu pengetahuan dan peningkatan kesadaran remaja tentang resiko kehamilan pada usia remaja. Seluruh hasil dari kegiatan ini dapat dilihat melalui table berikut ini:

Tabel.1 Distribusi peserta kegiatan

\begin{tabular}{llcc}
\hline No & \multicolumn{1}{c}{ Variabel } & Frekuensi & Persentase \\
\hline & Pendidikan & & \\
1 & SMP & 13 & $59 \%$ \\
2 & SMA & 9 & $41 \%$ \\
& Usia & & \\
1 & Remaja Awal & 14 & $64 \%$ \\
2 & Remaja Tengah & 8 & $36 \%$ \\
\hline
\end{tabular}

Dari tabel diatas dapat dilihat bahwa sebagian besar remaja berpendidikan SMP dengan presentase $59 \%$ dan sebagian besar remaja awal yaitu dengan persentase $64 \%$.

Tabel Rata - Rata Nilai dan Peningkatan Pengetahuan Peserta

\begin{tabular}{ccccc}
\hline $\begin{array}{c}\text { Nilai } \\
\text { Pretes }\end{array}$ & $\begin{array}{c}\text { Nilai } \\
\text { Post Test }\end{array}$ & $\begin{array}{c}\text { Rata-Rata } \\
\text { Kenaikan }\end{array}$ & Jml & $\begin{array}{c}\text { Presen } \\
\text { tase }\end{array}$ \\
\hline 62,1 & 80.3 & $2,3 \%$ & 25 & $100 \%$ \\
\hline
\end{tabular}

Secara umum, bila dilihat dari hasil pre test rata - rata nilai peserta sudah cukup. Tingkat pengetahuan disebabkan oleh beberapa faktor, antara lain: umur dan tingkat pendidikan. Selain faktor umur dan tingkat pendidikan, kurangnya pengetahuan responden 
juga dikarenakan kurang adanya sosialisasi atau penyuluhan khususnya tentang kesehatan reproduksi.

\section{SIMPULAN}

1. Terjadi peningkatan pengetahuan dan ketrampilan masyarakat terkait kesehatan reproduksi dan resiko kehamilan usia dini pada remaja

2. Remaja memahami bahaya kekehamilan dini

3. Kegiatan didukung oleh pemuda serta perangkat desa di Pulau nguan

\section{Dokumentasi kegiatan}

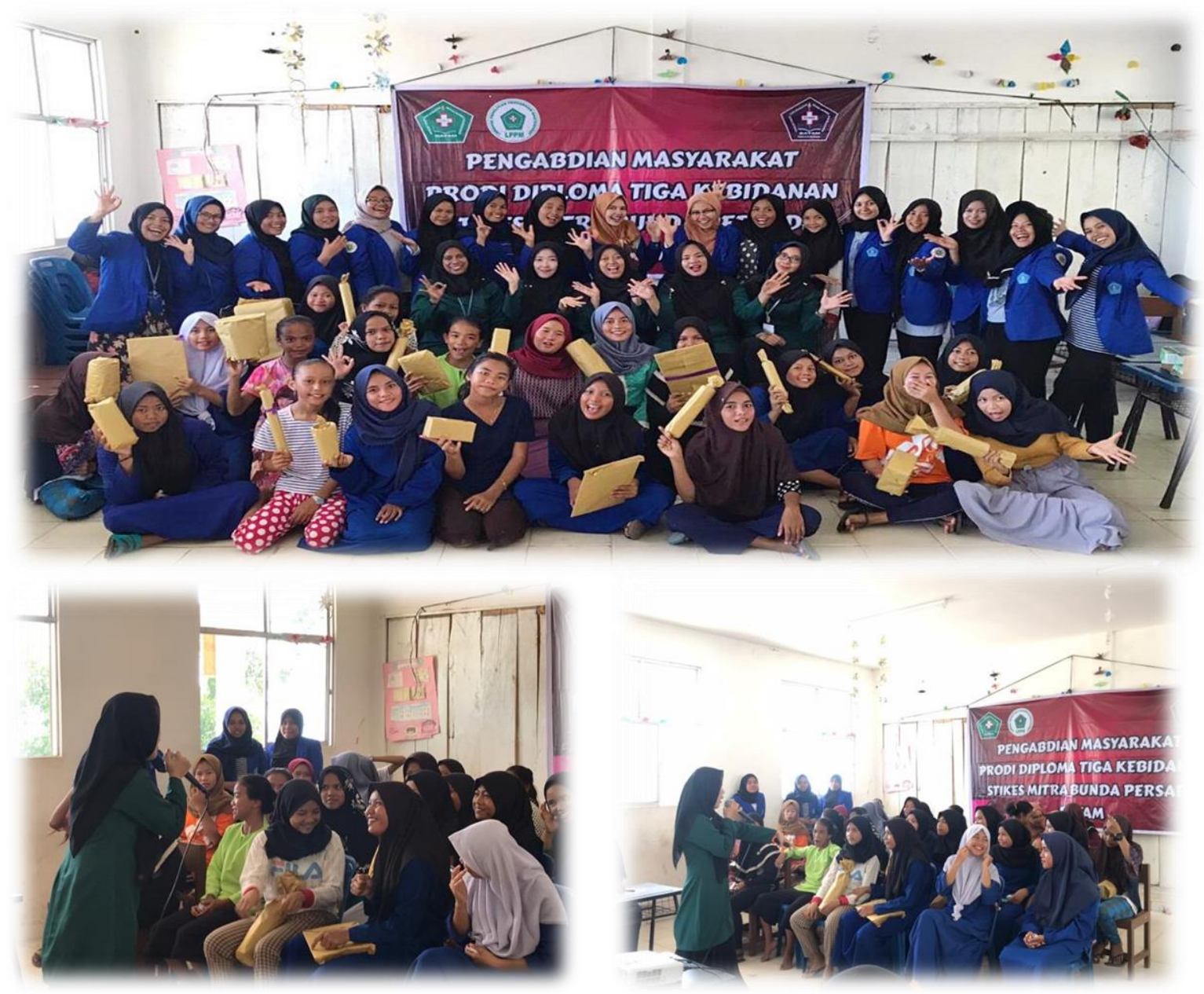




\section{DAFTAR PUSTAKA}

World Health Organization (WHO).2012. Early marriages, adolescent and young pregnancies.

Data PKPR Puskesmas Galang Kota Batam (2018). Data Laporan PKPR tahun 2018.

Profil Dinas Kesehatan Kota Batam. 2017.Riskesdas. Kementrian Kesehatan Tentang Proporsi Kehamilan Remaja. Oleh Pusdatin 2015.

Dinas Kesehatan Kota Batam, 2016. Data Masalah Remaja di Kota Batam Tahun 2017.

Isa I, Gani O. 2012. Socio-demographic determinants of teenage pregnancy in the Niger Delta of Nigeria. Open Journal of Obstetrics and Gynecology

Jones N, Tefera B, Stephenson J, Gupta T, Pereznieto P, Emire G, et al. 2014. Early marriage and education the complex role of social norms in shaping Ethiopian adolescent girls' lives: Overseas Development Institute

Kumalasari, 2012. Kesehatan Reproduksi. Jakarta : Salemba Medika.

Kusmiran, E. 2011. Kesehatan Reproduksi Remaja dan Wanita. Jakarta : Salemba Medika.

Marmi, 2013 .KesehatanReproduksi. Yogyakarta: Pustaka Pelajar.

Maternity, dkk. 2017. Asuhan Kebidanan Komunitas. Yogyakarta : CV. Andi Offset.

Mekonnen WA. 2013. Differentials of early teenage pregnancy in Ethiopia, 2000, and 2005: ICF International Calverton, Maryland, USA

Mchunu G, Peltzer K, Tutshana B, Seutlwadi L.2012. Adolescent pregnancy and associated factors in South African youth: African Health Sciences

Notoadmodjo, S. 2010. Metode Penelitian Kesehatan. Jakarta : Rineka Cipta.

Nugroho. 2011. Buku Ajar Obstetri untuk Mahasiswa Kebidanan. Yogyakarta : Nuha Medika.

Nursalam. 2013. Metodologi Penelitian Ilmu Keperawatan. Jakarta : Salemba Medika. 
Prawirohardjo. 2014. Ilmu Kebidanan. Jakarta : PT Bina Pustaka.

Pudiastuti, 2011. Buku Ajar Kebidanan Komunitas. Yogyakarta : Nuha Medika.

Ramlah, (2017). Asuhan Kebidanan Kesehatan Reproduksi Pada Remaja dengan Kehamilan Usia Remaja di Wilayah Kerja Puskesmas Sambau Kota Batam, Karya Tulis IImiah Studi Kasus, Batam. Program Studi D-III Kebidanan Stikes Mitra Bunda Persada Batam Tahun 2017.

Widyastuti dkk, 2010. Kesehatan Reproduksi. Yogyakarta: Fitra Maya.

Wall-Wieler E, Roos LL, Nickel NC. 2016. Teenage pregnancy: the impact of maternal adolescent childbearing and older sister's teenage pregnancy on a younger sister. BMC Pregnancy and Childbirth

World Health Organization (WHO).Departement of Reproductive Health and Research : Geneva 
Jurnal Pelayanan dan Pengabdian Masyarakat (PAMAS) 